At-Tarbawi: Jurnal Pendidikan, Sosial dan Kebudayaan

Volume 6 Nomor 2 Tahun 2019

doi: 10.32505/tarbawi.v6i2.1261

\title{
Memahami Perbedaan Individu Pebelajar dalam Proses Belajar Mengajar
}

\author{
Wahidah \\ IAIN Langsa \\ wahidah.bundanurul@gmail.com
}

\begin{abstract}
The purpose of writing this article is to explain how education understands the uniqueness of each student in individual learning or individual instruction. This writing method uses a descriptive analysis approach from several kinds of literature from journals, books and other documents. There are four aspects of individual differences that must be considered by teachers and principals in a teaching and learning process that includes physical-motor differences, intelligence differences, differences in language skills, and psychological differences. Understanding individual differences here is by carrying out individualized instruction (individual learning). Also provides opportunities for children to learn independently (Independent Study) by developing individual learning (individual instruction) following the level of their needs.
\end{abstract}

Keywords: Individual differences, Individual learning, independent learning

\begin{abstract}
Abstrak
Tujuan dari penulisan artikel ini adalah untuk menjelaskan bagaimana pendidikan yang memahami keunikan setiap siswa dalam pembelajaran individu atau individual instruction. Metode penulisan ini menggunakan pendekatan deskriptif analisis dari sejumlah literatur baik dari jurnal, buku maupun dokumen lainnya. Terdapat empat aspek perbedaan individual yang harus diperhatikan oleh guru dan kepala sekolah dalam suatu proses belajar mengajar yang meliputi perbedaan fisik-motorik, perbedaan intelegensi, perbedaan kecakapan bahasa, dan perbedaan psikologis. Memahami perbedaan individu disini adalah dengan melaksanakan individualized instruction (pembelajaran individu). Juga memberikan kesempatan kepada anak untuk belajar mandiri (Independent Study) dengan cara mengembangkan pembelajaran individual (individual instruction) yang sesuai dengan tingkatan kebutuhannya.
\end{abstract}

Kata Kunci: Perbedaan individu, Pembelajaran individu, belajar mandiri 


\section{A. Pendahuluan}

Pengembangan kurikulum melibatkan perumusan pendidikan yang biasa/berlaku untuk umum. Yaitu penetapan dan penilaian tentang apa yang harus seorang anak pelajari dan mampu untuk dilakukan. Namun bagaimanapun, setiap siswa itu tidak ada yang sama persis. Banyak perbedaan yang sangat tampak muncul pada tiap individu. Sehingga memaksakan hal yang sama harus terjadi dalam kelas yang heterogen akan menimbulkan masalah. Karena suatu kurikulum belum tentu bisa memenuhi kebutuhan semua anak yang ada di dalam suatu kelas.

Selain itu, perkembangan dalam berbagai sisi kehidupan terus saja terjadi dengan berbagai kompleksitasnya. Informasi dan teknologi semakin laju untuk dikonsumsi dan dipelajari. Pengaruh tekanan media informasi dan teknologi terus meningkat sehingga mempengaruhi akan banyaknya hal yang harus dipersiapkan bagi anak didik, namun waktu tak lagi cukup. Sehingga harus ada upaya kreatif dari orang tua/guru dalam proses pendidikan agar anak mampu mempelajari hal yang tidak sedikit itu. Salah satuya adalah dengan mengakomodir perbedaan siswa dalam proses pembelajaran.

Memahami perbedaan siswa adalah upaya yang membutuhkan usaha yang tidak ada habisnya. Peserta didik atau siswa menjadi sasaran utama pelaksanaan sistem pendidikan. Sistem pendidikan yang dilaksanakan diharapkan mampu menghasilkan insan yang berkualitas dari peserta didik atau siswa yang melaksanakan pembelajaran dalam sistem pendidikan yang diterapkan. Namun terkadang, penerapan proses pembelajaran yang seragam tidak mampu mengakomodir keunikan yang ada pada masingmasing siswa yang ada di suatu kelas. Dengan kata lain tidak mampu melejitkan potensi semua anak didik yang tergabung dalam suatu kelas. Karena sulitnya untuk memulai sebab tidak tau ingin memulai dari yang mana dan fokus pada apa. Sehingga untuk memudahkan proses belajar maka diambillah jalan pintas dengan disamakannya semua siswa. 
Padahal, setiap individu peserta didik adalah unik, limited edition, masing-masing memiliki kemampuan ataupun tingkatan serta karakter masing-masing. Dikarenakan para peserta didik memiliki karakter dan perbedaannya masing-masing, guru seharusnya dapat menentukan bagaimana perlakuan yang berbeda yang harus diterapkan pada masingmasing peserta didik, guru juga harus memperhatikan masing-masing siswa sehingga guru bukan hanya mampu memberikan perlakuan secara umum pada tiap kelompok atau tingkatan belajar, namun juga guru mampu memberikan perlakuan khusus yang tepat pada masing-masing individu terutama individu yang memiliki karakter/sifat/kecerdasan/kebiasaan yang berbeda dengan karakter peserta didik pada umumnya.

Perlakuan khusus sangat perlu untuk diberikan dan diterapkan pada masing-masing peserta didik dengan perlakuan yang berbeda pada tiap proses pembelajaran individual (individual instruction). Hal ini demi mempertimbangkan keunikan masing masing individu dengan segala kelebihan dan kekurangannya. Guru atau pengajar atau mentor tentu harusnya membuat perencanaan, pelaksanaan, dan penilaian yang berbeda antara pembelajaran pada individu satu dengan pembelajaran pada individu lainnya. Perbedaan-perbedaan tersebut sangat perlu untuk diperhatikan sehingga guru mampu mengelola dan melaksanakan pembelajaran individual maupun kelompok dengan tepat dan sesuai dengan sistem pendidikan yang dipakai dan diterapkan. Karena, ketidakmampuan guru untuk memahami individu dengan benar akan mengkerdilkan kelebihan yang lainnya yang seharusnya muncul menjadi kekuatan anak didik bila dikelola dengan benar. Memahami perbedaan individu tidak hanya dari tingkat kognitifnya saja namun hendaknya dari segala aspek yang mencakup perkembangan, gaya belajar, karakter (sifat), dan linkungan sosial tempat seorang anak didik tumbuh.

Sejatinya tujuan belajar harus sama dengan tujuan hidup, sebab pendidikan hanyalah alat yang dimanfaatkan manusia untuk memelihara kelanjutan hidup, baik sebagai individu maupun sebagai masyarakat. Setiap lembaga pendidikan baik formal maupun tidak, mempunyai cita cita 
tersendiri tentang bagaimana individu yang dicita citakan. Artinya, tidak semua tujuan yang di sepakati bersama dalam kurikulum nasional disetujui sepenuhnya oleh semua lembaga apalagi individu yang sangat kompleks dan beragam. Sehingga akan muncullah keunikan yang ada pada masing masing lembaga bahkan individu itu sendiri.

Memunculkan keunikan bukan berarti menolak pengalaman atau tujuan pendidikan orang lain dan menafikan persamaan yang mungkin ada, namun hal ini akan membuat dunia lebih berwarna karena setiap orang akan berperan sesuai dengan kemampuannya. Sehingga peran guru amat sangat akan bermakna dalam menentukan dan mengendalikan arah dan warna siswa dikemudian hari. Artikel ini akan mendiskusikan beberapa perbedaan individu yang hendaknya menjadi pertimbangan guru ketika mengelola kelas agara mampu memunculkan keunikan dan melejitkan kelebihan masing masing siswa yang unik itu. Memahami keunikan setiap disini adalah berupaya menciptakan pembelajaran invidu atau individual instruction. Metode penulisan ini menggunakan pendekatan deskriptif analisis dari sejumlah literatur baik dari buku maupun dokumen lainnya.

Banyak penelitian yang telah memaparkan tentang ragam dalam perbedaan individu dan upaya untuk menangani ataupun mensikapi perbedaan individu, maupun efek atau konsekuensi dari perbedaan itu. Salah satunya adalah penelitian Lin Aprilia, Sutaryadi, Tutik Susilowati, yang berjudul "Penanganan Perbedaan Individual Dalam Proses Pembelajaran Stenografi". Melalui metodologi penelitian kualitatif pendekatan studi kasus (case study) peneliti menjelaskan bahwa dengan mengingat adanya perbedaan-perbedaan yang terdapat pada diri masing-masing individual, maka menyamaratakan semua siswa ketika guru mengajar pada dasarnya kurang sesuai dengan prinsip individualitas. Berdasarkan hasil analisis data yang diperoleh oleh peneliti menunjukkan ada beberapa faktor-faktor yang mempengaruhi perbedaan individual dalam proses pembelajaran stenografi meliputi perbedaan latar belakang keluarga siswa, perbedaan tingkat kecerdasan, perbedaan kesiapan belajar, perbedaan persepsi dan minat siswa pada mata pelajaran stenografi. 
Untuk mengatasi perbedaan individu yang terjadi didalam kelas, guru melakukan metode penanggulangan dengan beberapa cara. Diantaranya adalah: memberikan bimbingan konseling kepada siswa. Hal ini dilakukan untuk mencari tau permasalahan yang mungkin akan mampu diselesaikan demi kelancaran dalam proses pembelajaran. Selanjutnya, guru memodifikasi berbagai jenis metode mengajar. Memvariasikan metode belajar memungkinkan siswa yang berbeda gaya belajarnya dapat memperoleh tujuan pembelajaran sesuai dengan yang ditentukan.

Selain itu, kelompok belajar dalam jumlah yang kecil juga diupayakan didalam kelas. Sehingga lebih mudah untuk mengontrol perkembangan dan kemajuan siswa. Guru juga hendaknya peduli dengan kompetensi siswa yang berbeda satu sama lain. Memberikan system pembelajaran modul dengan memberikan apersepsi sebelum pembelajaran stenography dimulai. Sehingga ketika kelas dimulai siswa telah memiliki persiapan yang matang atau paling tidak sudah memiliki gambaran tentang hal yang akan dipelajari. Dalam menjalankan upaya penanggulan ada beberapa tantangan yang dihadapi. Di antaranya yaitu: proses belajar mengajar di setting dalam kelas klasik pada umumnya, sehingga bimbingan yang sesuai dan maksimal tidak dapat dilakukan. Kemudian, sulitnya menentukan metode belajar yang sesuai untuk mengkonter semau kebutuhan siswa. Kelas yang diseting dalam skala besar juga menyulitkan guru untuk memperhatikan perbedaan kompetensi siswa. Tidak semua mampu memahami modul yang diberikan dan bahkan tidak menyelesaikna tugas yang diberikan.

Selanjutnya penelitian yang dilakukan oleh Yuliana, dengan judul "Pengaruh Perbedaan Individu Terhadap Keputusan Menggunakan Sistem Operasi Linux". Peneliti menggunakan pendekatan manajemen pemasaran dan jenis penelitian ini adalah penelitian deskriptif dan verifikatif yang dilakukan pada kurun waktu kurang dari satu tahun. Perkembangan system operasi dan era digital adalah dua aspek yang berhubungan dan terintegrasi. System operasi linux adalah yang sedang berkembang saat ini. Namun, perkembangan linux tidak sebanding dengan usianya yang telah lama sejak 1991. Hal ini ditandai dengan rendahnya pengguna system operasi linux ini. 
Untuk menganalisis rendahnya pengguna linux maka dilakukanlah analisis perbedaan individu. Tujuannya untuk mengetahui gambaran perbedaan individu, keputusan menggunakan, dan pengaruh perbedaan individu dalam menggunakan system operasi tersebut.

Hasil penelitian juga menyatakan bahwa perbedaan individu mempunyai pengaruh positif terhadap keputusan menggunakan dengan tingkat korelasi sangat kuat. Hal ini menunjukkan bahwa semakin bervariasi perbedaan individu, maka akan semakin tinggi pula keputusan menggunakannya. Dengan pengetahuan tentang konsep tersebut maka sumber manusia yang dihasilkan oleh pendidikan manajemen bisnis selain ahli dalam bidang keuangan dan kewirausahaan, juga ahli dalam bidang pemasaran.

Penelitian lainnya adalah dari Raymond flores dengan judul 'The Impact of Adapting Content for Students with Individual Differences'. Dalam penelitian ini dia mengkombinasikan metode hypermedia yang bisa di adaptasi dengan strategi dari media pembelajaran. Tujuan penelitian ini untuk mendesain dan mengembangkan tutorial yang dapat diadaptasi bagi semua siswa. Kemudian diukur apakah pembelajaran individu (individualized instruction) sesuai dengan motivasi dan pengetahuan terdahulu yang dimiliki seorang siswa atau tidak. Selain itu juga untuk mengidentifikasi masalah berkaitan dengan kegunaaan tutorial pembelajaran individu agar fungsinya dapat ditingkatkan. Ada sekitar 186 siswa dilibatkan dalam 2 tahapan dipenelitian ini. Data diperoleh melaui interview, kuesionaire, survey, dan fokus grup diskusi. Hasilnya menunjukkan bahwa secara keseluruhan mahasiswa senang dengan pengalamannya dan sebagian dari mereka juga memperoleh manfaat yang lebih.

\section{B. Metode}

Metode penelitian ini menggunakan studi kepustakaan untuk menelaah melalui tulisan dari buku mengenai perbedaan individu, keragaman, dan kaitannya dengan kurikulum. 


\section{Hasil dan Pembahasan}

\section{Perbedaan Individual}

Perbedaan individu (individual differences) adalah suatu perbedaan yang dimiliki oleh setiap individu baik fisik maupun non fisik yang menjadikan seseorang memiliki karakter/ ciri-ciri yang berbeda antara satu dengan yang lain. Perbedaan individu merupakan faktor penting sebagai dasar pengembangan individualized instruction. Beberapa perbedaan yang sangat penting diperhatikan dalam proses pengajaran adalah perbedaan kemampuan dasar atau bakat, minat, kecepatan dan cara belajar anak. Setiap anak memiliki kemampuan dasar bawaan, dan akan mengalami perubahan karena pengalaman, karena kebutuhan anak dan kemampuan dasar bawaannya berbeda maka minat anak dalam belajar akan berbeda juga.

Masalah individu mendapat perhatian yang besar dalam kajian psikologi, sehingga melahirkan suatu cabang psikologi yang dikenal dengan indivual psychology, atau differential psychology, yang memberikan perhatian besar terhadap penelitian tentang perbedaan antar individu. Ini didasarkan atas kenyataan bahwa di dunia ini tidak ada dua orang yang persis sama. Sedangkan dalam tinjauan psikologi Islam, perbedaan individual tersebut dipandang sebagai realitas kehidupan manusia yang sengaja diciptakan Allah untuk dijadikan bukti kebesaran dan kesempurnaan ciptaan-Nya.

Pengembangan pengajaran individual (individualized instruction) bukanlah pengajaran harus berdasar atas jalannya satu orang guru dengan satu orang murid, akan tetapi pengajaran dengan guru memberikan pelayanan yang berbeda pada setiap anak sesuai dengan perbedaanperbedaan individu itu. Individualized instruction merupakan usaha melengkapi kondisi belajar yang optimum bagi setiap individu murid.

Pengajaran individual merupakan suatu upaya untuk memberikan kesempatan kepada siswa agar dapat belajar sesuai dengan kebutuhan, kemampuan, kecepatan dan caranya sendiri. Karena belajar merupakan potensi dasar manusia yang perlu dirawat, dikuatkan, disadarkan dan dikelola dengan benar agar hasilnya maksimal dan menjadi peran inovatif bagi peradaban. 
Sejalan seperti kata Charlotte Mason, "kita tidak bisa memastikan buku yang mana yang akan menggetarkan jiwa seorang anak, lukisan atau komposisi mana yang akan memantik apresiasi seninya, kunjungan ketempat historis mana yang akan membangkitkan kesadaran sejarahnya. Setiap anak akan member respon secara berbeda sesuai keunikan minat dan kepribadiannya. Yang bisa dilakukan dan di upayakan guru maupun orang tua adalah membuka akses selebar lebarnya untuk mereka pada seberagam mungkin ide yang berharga.

\section{Aspek-Aspek Perbedaan Individual}

Berikut ini beberapa aspek perbedaan individual peserta didik: Pertama, perbedaan fisik-motorik. Perbedaan individual dalam fisik tidak hanya terbatas pada aspek-aspek yang teramati oleh panca indra, seperti bentuk atau tinggi badan, warna kulit, warna mata atau rambut, jenis kelamin, nada suara atau bau keringat, melainkan juga mencakup aspek-aspek fisik yang tidak dapat diamati melalui pancaindra, tetapi hanya dapat diketahui setelah diadakan pengukuran, seperti usia, kekuatan badan atau kecepatan lari, golongan darah, pendengaran, penglihatan, dan sebagainya.

Aspek fisik lain dapat dilihat dari kecakapan motorik, yaitu kemampuan melakukan koordinasi kerja sistem saraf motorik yang menimbulkan reaksi dalam bentuk gerakan-gerakan atau kegiatan secara tetap, sesuai antara rangsangan dan responnya. Dalam hal ini, akan ditemui ada anak yang cekatan dan terampil, tetapi ada pula anak yang lamban mereaksi sesuatu.

Kedua, Perbedaan Intelegensi. Intelegensi adalah salah satu kemampuan mental, pikiran atau intelektual dan merupakan bagian dari proses-proses kognitif pada tingkatan yang lebih tinggi. Para ahli mendefinisikan dan merumuskan istilah intelegensi secara beragam, namun sebagian besarnya sepakat bahwa definisi dan rumusan istilah intelegensi memiliki sejumlah kualitas tertentu sebagi berikut:

a) Bersifat adaptif, artinya dapat digunakan secara fleksibel untuk merespon berbagai situasi dan masalah yang dihadapi. 
b) Berkaitan dengan kemampuan belajar, orang yang inteligen dibidang tertentu dapat mempelajari informasi-informasi dan perilaku-perilaku baru dalam bidang tersebut secara lebih mudah dibandingkan orang yang kurang inteligen.

c) Istilah intelegensi juga merujuk pada penggunaan pengetahuan yang sebelumnya telah dimiliki untuk menganalisis dan memahami situasisituasi baru secara efektif.

d) Istilah intelegensi melibatkan interaksi dan koordinasi yang kompleks dari berbagai proses mental.

e) Istilah intelegensi terkait dengan budaya tertentu (culture specific). Perilaku yang dianggap inteligen dalam suatu budaya tertentu tidak selalu dianggap perilaku yang inteligen dalam budaya lain.

Ketiga, Perbedaan Kecakapan Bahasa. Perbedaan individual dalam perkembangan dan kecakapan bahasa anak ini telah menjadi wilayah pengkajian dan penelitian yang menarik bagi sejumlah psikolog dan pendidik. Banyak penelitian eksperimen telah dilakukan untuk menentukan faktor-faktor yang mempengaruhi keberhasilan atau kegagalan dalam penguasaan bahasa anak. Dari sejumlah hasil penelitian tersebut diketahui bahwa faktor nature dan nuture individu itu bervariasi, maka pengaruhnya terhadap perkembangan bahasa juga bervariasi. Oleh sebab itu, antara individu yang satu dan individu lainnya berbeda dalam kecakapan bahasanya. Perbedaan kecakapan berbahasa anak ini sangat dipengaruhi oleh berbagai faktor, seperti faktor kecerdasan, pembawaan, lingkungan, fisik, terutama organ bicara dan sebagainya.

Keempat, Perbedaan Psikologis. Perbedaan individual peserta didik juga terlihat dari aspek psikologinya. Ada anak yang mudah tersenyum, ada anak yang mudah marah, ada yang berjiwa sosial, ada yang sangat egoistis, ada yang cengeng, ada yang pemalas, ada yang rajin, ada yang pemurung dan sebagainya. Persoalan psikologis memang sangat kompleks dan sangat sulit dipahami secara tepat, sebab menyangkut apa yang ada di dalam jiwa dan perasaan peserta didik. Guru dituntut untuk mampu memahami fenomena- 
fenomena psikologis peserta didik yang rumit tersebut. Salah satu cara yang mungkin dilakukan dalam menyelami aspek psikologis peserta didik ini adalah dengan melakukan pendekatan kepada peserta didik secara pribadi. Guru harus menjalin hubungan yang akrab dengan pesert didik, sehingga mereka mau mengungkapkan isi hatinya secara terbuka. Guru dapat mengenal siapa sebenarnya peserta didik sebagai individu, apa keinginankeinginannya, kebutuhan-kebutuhannya, apa yang ingin dicapainya, masalahmasalah apa yang telah dihadapinya, dan sebagainya. Guru mendekati dan mengenal peserta didik secara mendalam, dan mencari cara-cara yang tepat untuk memberikan bimbingan dan membangkitkan motivasi belajar mereka.

\section{Pengaturan atau Pelayanan yang dapat di Kembangkan menuju Individualized Instruction}

Beberapa pengaturan dan pelayanan yang dapat dilakukan oleh kepala sekolah dan guru-guru dalam kelas untuk pengembangan Individualized Instruction tanpa melupakan peranan yang seharusnya dilakukan oleh pembuat kebijaksanaan tingkat lokal atau pusat. Ini dimaksudkan agar kepala sekolah atau guru-guru dalam kelas terdorong untuk lebih berusaha dalam batas kewenangannya mengadakan pelayanan kepada peserta didik sesuai dengan perbedaan individualnya, di antaranya:

Pertama, pengaturan atau pelayanan sekolah. Menurut Sodiq A. Kuntoro dalam Suryobroto pelayanan sekolah ini meliputi penyediaan perpustakaan, program khusus dan alat pengajaran yang memadai. Untuk mengembangkan pengaturan atau pelayanan sebagai berikut:

a) Perpustakaan yang memadai untuk studi individual. Untuk mengembangkan Individualized Instruction maka perlu sekali tersedianya fasilitas perpustakaan yang cukup, yang memberi kemungkinan setiap anak dapat belajar secara individual. Dalam program belajar mandiri (Independent Study) atau aktivitas program pengayaan bagi anak cepat. Perpustakaan merupakan tempat dan fasilitas penting, tanpa ada perpustakaan yang memadai maka sangat sulit untuk dapat melaksanakan program Independent Study atau pengayaan itu. 
b) Penyediaan alat pengajaran dan program pelayanan yang memberi fasilitas Individualized Instruction, meliputi; Laboratorium atau workshop yang memadai. Jadwal pelajaran yang fleksibel, yang memungkinkan beberapa murid tingkat II misalnya mengikuti pelajaran tingkat III dalam mata pelajaran tertentu. Pengembangan program Independent Study. Pengembangan program penyuluhan dan bimbingan. Pengembangan team-teaching.

Kedua, Pengaturan atau pelayanan dalam kelas. Kebijakan ini dapat dilakukan oleh guru. Menurut Sodiq A. Kuntoro (1978) yang dikutib dalam Suryobroto (2009) beberapa usaha yang dapat dilakukan oleh guru dalam kelas adalah meliputi : program perbaikan (Remidial), program pengayaan (Enrichment), program percepatan (Acceleration), Achievement Grouping, Independent Study, dan mengembangkan program individual. Dari sekian banyak bentuk program pendidikan yang dapat dipilih, terdapat tiga jenis program yang terbanyak dilaksanakan, yaitu program Remidial, program pengayaan (Enrichment), dan program percepatan (Acceleration).

1) Bagi anak lambat, program yang dapat dikembangkan adalah program Remidial (perbaikan). Program Remidial adalah pemberian layanan pendidikan kepada siswa yang mengalami kesulitan atau hambatan dengan memberikan pelajaran atau tugas tambahan secara individual sehingga mereka dapat mengikuti pembelajaran secara klasikal dan menyelesaikan program sesuai dengan waktu yang ditentukan serta mencapai hasil belajar secara optimal.

2) Bagi anak sedang, program yang dapat dikembangkan, yaitu Enrichment (Pengayaan). Program pengayaan ialah pemberian program tambahan bagi anak sedang untuk pedalaman, perluasan bahan yang telah dikuasai atau lebih jauh untuk pengembangan kemampuan analisis, pemecahan masalah atau penerapan ilmu yang telah mereka kuasai. Ini berarti bahwa tujuan program pengayaan tidak hanya bersifat penambahan bahan pelajaran saja, akan tetapi lebih jauh mengembangkan kemampuan anak untuk melakukan analisis, pemecahan masalah, atau 
menggunakan ilmu dalam kehidupan sehari-hari. Bentuk program pengayaan bermacam-macam seperti mempelajari bahan diatasnya, diselenggarakan kelas khusus untuk pengayaan, penambahan pelajaran melalui mencari bahan di surat kabar, artikel-artikel, melakukan percobaan, penelitian, dan lain-lain.

3) Bagi anak cepat, program yang dikembangkan yaitu acceleration (percepatan). Program percepatan adalah pemberian pelayanan pendidikan sesuai potensi kecerdasan dan bakal istimewa yang dimiliki siswa, dengan memberi kesempatan kepada mereka untuk dapat menyelesaikan program dalam jangka waktu yang lebih singkat dibanding teman-temannya.

4) Pengelompokan anak atas prestasi belajarnya (achievement grouping). Ada dua macam pengelompokan, yaitu homogen (pengelompokan menjadi satu anak-anak yang sama prestasi belajarnya), dan pengelompokan heterogen (setiap kelompok justru dari anak-anak yang berbeda prestasi belajarnya).

5) Memberikan kesempatan kepada anak untuk belajar mandiri (Independent Study). Guru dalam kelas seharusnya memberi kesempatan dan melatih anak untuk dapat belajar sendiri. Belajar di perpustakaan atau dilaboratorium merupakan aktivitas penting untuk Independent Study.

6) Mengembangkan Program pembelajaran Individu. Guru dalam kelas dapat mencoba mengembangkan program paket untuk program mini seperti menyediakan modul modul tertentu yang bermanfaat bagi pengembangan individu. Pembelajaran individu berorientasi pada individu dan pengembangan diri. Fokusnya adalah pada proses dimana individu membangun dan mengorganisasikan dirinya secara realitas yang bersifat unik satu sama lainnya. Hal ini memungkinkan setiap siswa dapat belajar sesuai dengan kemampuan potensinya, juga memungkinkan setiap siswa menguasai seluruh bahan pelajaran secara penuh atau disebut juga dengan mastery learning atau belajar tuntas. Strategi pengajaran yang menganut konsep belajar tuntas, sangat 
mementingkan perhatian terhadap perbedaan individual. Atas dasar ini sistem penyampaian pengajaran dilakukan dengan mengarah kepada siswa belajar secara individual.

Berdasarkan penjelasan di atas maka guru-guru dalam kelas dan kepala sekolah dalam batas kewenangannya seharusnya menyelenggarakan program pelayanan atau pengaturan yang mendukung terciptanya Individualized Instruction dengan menyediakan sarana dan prasarana yang sesuai.

\section{KESIMPULAN}

Perbedaan individual (individualized differences) merupakan pengajaran yang memperhatikan atau berorientasi pada perbedaanperbedaan individual anak. Pembelajaran individual (individualized instruction) bukanlah pengajaran harus berdasar atas jalannya satu orang guru dengan satu orang murid, akan tetapi pengajaran dengan guru memberikan pelayanan yang berbeda pada setiap anak sesuai dengan perbedaan-perbedaan individual itu. Individualized instruction merupakan usaha melengkapi kondisi belajar yang optimum bagi setiap individu murid. Aspek-aspek perbedaan individual meliputi perbedaan fisik-motorik, perbedaan intelegensi, perbedaan kecakapan bahasa, dan perbedaan psikologis. Terdapat tiga jenis program yang terbanyak dilaksanakan, yaitu; bagi anak lambat, program yang dapat dikembangkan adalah program Remidial (perbaikan). Bagi anak sedang, program yang dapat dikembangkan, yaitu Enrichment (Pengayaan). Bagi anak cepat, program yang dikembangkan yaitu acceleration (percepatan). Pengelompokan anak atas prestasi belajarnya (achievement grouping). Memberikan kesempatan kepada anak untuk belajar bebas (Independent Study). Mengembangkan program individual. 


\section{DAFTAR PUSTAKA}

Aprilia, L. (2013). Penanganan Perbedaan Individual Dalam Proses Pembelajaran Stenografi. Jurnal Pendidikan administrasi perkantoran.

Arifin, M. (2009). Ilmu Pendidikan Islam: Tinjauan Teoretis dan Praktis Berdasarkan Pendekatan Interdisipliner. Jakarta: Bumi aksara.

ARY, D., JACOBS, L. C., \& SORENSEN, C. (2010). Introduction to Research in Education. Canada: Wadsworth.

Bordens, K. S., \& Abbott, B. B. (2008). RESEARCH DESIGN AND METHODS. New YorkMcGraw-Hill.

Borg, W. R., \& Gall, M. D. (1989). Educational Research: An Introduction. New York: Longman.

Buckingham, M., \& Clifton, D. (2001). Now, discover your strengths: How to develop your talents and those of the people you manage. London: Simon \& Schuster.

Creswell, J. W. (2012). Educational Research. Boston: Pearson.

Dewi Citra Sari. (2017). Magang Yuk! Merancang Aktivitas magang ala AB Home. Depok: Penerbit Tosca.

Flores, R. (2012). The Impact of Adapting Content for Students with Individual Differences. Educational Technology \& Society.

Langgulung, H. (2004). Manusia dan Pendidikan. Jakarta: Pustaka Alhusna Baru.

Langgulung, H. (1985). Pendidikan dan Peradaban Islam. Jakarta: Pustaka Alhusna.

Milan, J. H. (2008). Educational Research. Boston: Pearson Education.

Moh. Nazir, P. D. (2011). Metode Penelitian. Ciawi- Bogor: Ghalia Indonesia.

Muhaimin, P. D. (2006). Nuansa Baru Pendidikan Islam. Jakarta: Raja Grafindo Persada.

Rich, D., \& Mattox, B. (2009). Metode Mega skillls. Jakarta: Mizan publika.

Royani, A. R., \& Aji, E. P. (2017). Talents Dynamics. Depok: PT. Tosca Jaya.

Santosa, H. (2018). Fitrah Based Education. Depok: Yayasan Cahaya Mutiara Timur. 
Slameto. (2003). Belajar dan Faktor-Faktor yang Mempengaruhinya. Jakarta: Asdi Mahasatya.

Solichin, M. M. (2007). fitrah; konsep dan pengembangannya dalam pendidikan islam. Tadrish, 236.

Suparman, M. A. (2012). Desain Instruksional modern. Jakarta: Erlangga.

Uher, J. (2018, Februari 26). Taxonomic models of individual differences: a guide to transdisciplinary approaches. Retrieved September 2, 2019, from Royalsocietypublishing.org: https://royalsocietypublishing.org/doi/full/10.1098/rstb.2017.0171

Yuliana. (2016). Pengaruh Perbedaan Individu terhadap Keputusan Menggunakan Sistem Operasi Linux. Journal of business management education. 
